\begin{tabular}{lcccc} 
POLISH & JOURNAL & OF & SOIL & SCIENCE \\
\hline VOL. XLVII/1 & 2014 & PL ISSN 0079-2985
\end{tabular}

Soil Chemistry

\title{
VALENTINA TRIGUB* STEPAN POZNYAK** \\ THE IMPACT OF PHOSPHOGYPSUM ON THE ACCUMULATION AND MIGRATION OF FLUORINE IN SOILS AND SOIL SOLUTIONS
}

Abstract. The results of the study of the impact of phosphogypsum on the accumulation and migration of fluorine in the southern chernozems of the North-West Black Sea coast area of Ukraine are presented herein. It has been found that the introduction of phosphogypsum as a chemical ameliorator of irrigated chernozems resulted in a fluorine increase both in the soils and in the soil (lysimetric) waters.

Despite the sharp decrease in volumes and rates of introduction of mineral and organic fertilizers in the last decade, the degree of pollution of the soils of the southern chernozems of the North-West Black Sea coast area of Ukraine, which are intensively exploited in agriculture, remains high. The state of the soils of the agricultural landscapes of southern Ukraine is, to a large extent, conditioned by the consequences of long-term melioration and chemicalization of intensive agriculture and closely connected with the peculiarities of agricultural exploitation of lands.

Mineral fertilizers produce the greatest geochemical impact on soils and bioproduction of agricultural landscapes among main means of chemicalization $[6,13]$. Phosphoric fertilizers contain the widest spectrum of concentrating chemical elements among standardized fertilizers. Strontium, fluorine and lead have the greatest concentrations in phosphoric fertilizers. In the case of systematic incorporation of phosphoric fertilizers, especially in higher doses, ballast

* V.Trigub, DSc.; Odessa National University named after I. I. Mechnikov, Department of Soil Science and Soil Geography, Dvoryanskaya St. 2, Odessa, 65026, Ukraine.

** Prof. S. Poznyak, DSc.; Ivan Franko National University of Lviv, Department of Soil Science and Soil Geography, Doroshenka St. 41, Lviv, 79000, Ukraine. 
elements can accumulate in the soil in considerable quantities and produce a negative impact on its properties and fertility $[3,5,6,8,9,12]$.

Phosphogypsum, which in addition to containing such elements of plant nutrition as calcium, phosphorus and sulphur, also contains a great amount of admixtures, among which fluorine occupies a special place from the point of view of polluting soils and adjacent media, is widely applied in agriculture.

The content of fluorine in phosphogypsum is changeable and varies in the interval between 1.0 and 5.0\%. However, taking into account the pollution of soils with fluorine, the greatest portion of phosphogypsum supplied for agriculture is subject to "defluorination" with the reduction of fluorine to tenths of a percent at the chemical factory. Nevertheless, when phosphogypsum is introduced in high doses and applied systematically for a long time, the danger of pollution of agricultural landscapes with fluorine remains imminent.

For fluorine geochemistry, low $\mathrm{CAF}_{2}$ solubility $\left(2.1-10^{-30} \%\right)$ is of great importance, as predetermines the possibility of its sedimentation on the calcium barrier. This property is very important for chernozem soils of southern Ukraine. Calcium reserves in the soils of the steppe zone are very large. Calcium can be found in the $\mathrm{B}$ and $\mathrm{C}$ horizons of both solonetz and zonal soils in the form of $\mathrm{CaCO}_{3}, \mathrm{CaSO}_{4}, 2 \mathrm{H}_{2} \mathrm{O}$. According to Perelman, the research on fluorine migration in arid landscapes is considered mainly with taking into account the fluorine sedimentation by carbonates of salts and rocks, which reduces the possibility of accumulation of the mobile forms in the soil profile [7]. Meanwhile, the introduction of phosphoric fertilizers, especially phosphogypsum, as a chemical ameliorator of irrigated chernozems makes the problem of pollution of steppe landscapes of southern Ukraine with fluorine urgent. The aim of our research was to study the fluorine content in the agricultural landscapes of the NorthWest Black Sea Coast of Ukraine in connection with irrigation and application of phosphogypsum as a chemical ameliorator of salted soils. Special attention was paid to the study of the fluorine content in southern chernozems, which are the main production resource on the one hand, and an active geochemical barrier on the way of migration of the elements, on the other. In this respect, the irrigated soils represent the most vulnerable landscape component as the waters used for irrigation, as well as fertilizers, are an additional source of polluting substances, including fluorine.

\section{MATERIAL AND METHODS}

Objects of the research were as follows: southern chernozems of warm Southern European facies, both irrigated and dry, as well as the soil and ground waters. The research was carried out on the experimental site (Odessa region). The scheme of the experiment was as follows: 
1 - southern chernozems, non-irrigated, absolute control;

2 - southern chernozems, irrigated, control;

3 - southern chernozems, irrigated with the introduction of phosphogyp$\operatorname{sum}(12 \mathrm{t} / \mathrm{ha})$.

The main soil profiles were located in an immediate vicinity of each other - within one geomorphological level - in similar relief conditions. In addition to the main cuts, a number of miniprofiles were made. The main soil cuts were made to $150 \mathrm{~cm}$ depth, i.e. to soil-forming rocks. Soil samples for laboratory analysis were taken from these cuts, layer-by-layer, with an account of the genetic horizons.

The following three groups of fluorine forms were studied on the basis of literature sources:

1 - immediate reserve - water-soluble fluorine;

2 - closest reserve - acid-soluble fluorine;

3 - remote reserve - total content of fluorine.

In the performed research, the main attention was paid to the study of the active fluorine content, as it is the form of the microelement that is the most mobile and available for plant nutrition.

In order to study the vertical fluorine migration, lysimers were installed into the walls of the soil cuts in the sections under study, at the depth of 30 and $60 \mathrm{~cm}$, in a two-fold repetition and without disturbing the natural composition. The sampling of the lysimetric waters was performed three times per year - in spring, summer and autumn.

The content of fluorine in the southern chernozems and lysimetric waters was determined using the potentiometric method with an application of the F-selective EF - IV electrode.

The migration ability of fluorine (coefficient of water migration) was determined by the ratio of the element atoms, which passed into the mobile state (into the water), to the number of its atoms in the soil [4].

\section{RESULTS AND DISCUSSION}

Irrigation is one of the most effective techniques of increasing the productivity of crop cultures for territories located the arid climate zone and one of the powerful types of anthropogenic impact. It results not only in additional moistening, but also a deep geochemical transformation of landscapes. In the case of optimal natural preconditions and norms of irrigation, the water and heat regime of soils improves, their microbiological activity enhances, the leaching of easily soluble salts reduces soil salinization and the biological productivity of agricultural landscapes increases [4]. 
It is common knowledge that under the conditions of irrigation, the demand of plants for nutritional elements increases significantly, and therefore the effectiveness of the fertilizers increases. Fluorine appears to be in the first minimum of elements of root nutrition of plants on irrigated chernozems. This can be explained by the fact that in chernozems, which are relatively rich in total phosphorus, a prevailing part of phosphates is in the form that is non-soluble and unavailable for plants. This, in turn, conditions the necessity of introducing higher doses of phosphoric fertilizers. Chibiny apatites, the composition of which includes three phosphorus-containing minerals: chloroapatite $\mathrm{Ca}_{5} \mathrm{CI} /$ $\mathrm{PO}_{4 / 3}$, hydroxyl apatite- $\mathrm{Ca}_{5} / \mathrm{OH} / \mathrm{PO}_{4 / 3}$ and fluoroapatite $-\mathrm{Ca}_{5} \mathrm{~F} / \mathrm{PO}_{4 / 3}$, are the main raw material for the production of phosphoric fertilizers in CIS. The ratio between these elements in the raw material can be different, which is why phosphoric fertilizers supplied to the agricultural industry (superphosphate, double superphosphate, prezinitate, etc.) always contain larger or smaller quantities of biologically toxic fluorine in their composition.

Problems of studying the impact of irrigation on properties of the soils in the studied region are presented in numerous works $[2,10,11]$. As to the study of accumulation and migration of fluorine resulting from the introduction of phosphogypsum into the system "soil-lysimetric waters", it was the first experiment of this kind on the studied territory.

Different points of view exist regarding the possibility of polluting the soils with fluorine as a result of irrigation and long-term application of phosphoric fertilizers. The results of our research on identification of the impact of irrigation water and higher doses of phosphogypsum on the content of total and active fluorine in southern chernozems, are presented in Tables 1 and 2.

The content of total fluorine in non-irrigated southern chernozems is higher than in their irrigated counterparts. This is related to the additional moistening and gradual transition of some quantities of total forms of the microelement into soluble form (Table 1). This research confirms [10] that with considerable washing of the soil, fluoric compounds are redistributed in the soil profile and can be brought out beyond its limits, despite their low solubility. In the $\mathrm{B}$ and $\mathrm{C}$ horizons, the quantity of fluorine is similar and depends mainly on the quantity of carbonates in the soil.

The content of the soluble forms of fluorine in the case of irrigation also resulted in an increase in the microelement in the upper horizons of southern chernozems, especially the acid-soluble forms (Table 2). The lowest concentrations of fluorine were determined in the non-irrigated southern chernozems. 
TABLE 1. THE CONTENT OF FLUORINE IN THE ARABLE LAYER OF SOUTHERN CHERNOZEMS OF THE NORTH-WEST BLACK SEA COAST OF UKRAINE $\left(\mathrm{mg} \mathrm{kg}^{-1}\right)$.

\begin{tabular}{|l|c|c|c|}
\hline \multirow{2}{*}{ Fluorine } & \multicolumn{3}{|c|}{ Experiment variant, soils } \\
\cline { 2 - 4 } & Non-irrigated & Irrigated & $\begin{array}{c}\text { Irrigated }+ \\
\text { phosphogypsum (12t/ha) }\end{array}$ \\
\hline Total & $\frac{380.0-597.0}{488.5}$ & $\frac{310.0-328.0}{319.2}$ & $\frac{318.0-360.5}{334.4}$ \\
\hline Acid-soluble & $\frac{4.56-5.60}{5.08}$ & $\frac{10.45-13.30}{11.93}$ & $\frac{14.73-19.95}{17.08}$ \\
\hline $\begin{array}{l}\text { Water- } \\
\text { soluble }\end{array}$ & $\frac{0.49-3.96}{1.92}$ & $\frac{2.1-3.44}{2.77}$ & $\frac{2.05-6.75}{4.12}$ \\
\hline
\end{tabular}

The numerator represents limits of the content; the denominator represents the average value.

In the case of irrigation, the amount of water-soluble fluorine increases everywhere but especially high concentrations are characteristic of the irrigated gypsumed soils. Water-soluble forms are characterized by some fluctuations in the fluorine content depending on the granulometric composition, amount of humus, easily soluble salts and carbonate content in the soils. There was also a corresponding increase in the acid-soluble fluorine content in the irrigated and especially irrigated gypsumed soils (more than threefold).

One of the main unfavorable consequences of introducing the phosphoric fertilizers is their accumulation in ground and surface waters. The accumulation of fluorine in soil waters is influenced by the degree of mobility of fluorides (DM) [10], which can increase as a result of additional moistening (irrigation) and introduction of fluorine-containing fertilizers. The degree of mobility of fluorides is calculated by the ratio of the content of water-soluble fluorides and their bulk content in the soil (Table 2). Despite the low solubility and mobility of fluorine in chernozem soils, the introduction of phosphogypsum increased the degree of water-soluble fluorine mobility two times, with a 1.5 increase in the degree of acid-soluble fluorine.

In order to determine the intensity of fluorine migration in the profile, its content in lysimetric waters was studied. The study of lysimetric waters makes it possible to determine the degree of the anthropogenic impact on soil processes in order to identify the regularities in the movement of pollutants in the soils, to estimate the role of soil as a natural filter for elements and their compounds, as well as to determine their impact on the composition of ground waters, formed at the expense of the soil runoff.

The averaged data, obtained for the two-year period of observation, was used in this study. The content of fluorine in the studied irrigation waters was 
between 0.39 and $0.43 \mathrm{mg} / \mathrm{l}$. The content of fluorine in lysimetric waters on the control variant varied between 0.13 and $0.22 \mathrm{mg} / 1$, which is $1.5-3$ times lower than the content of fluorine in the irrigation water. Thus, field research of lysimetric waters confirmed the high absorptive ability of chernozem soils with respect to fluorides, contained in the irrigation waters (Table 2).

On irrigated sites, where phosphogypsum was introduced, the content of fluorine increased in certain cases more than two times, which attests to the high migration activity of fluorine in the studied soils. The research data is confirmed by calculations of the migration activity of fluorine in lysimetric waters of the experimental sites (control one, as well as the site with introduction of phosphogypsum).

TABLE 2. INDICES OF THE DEGREE OF MOBILITY OF FLUORIDES (\%) AND THE COEFFICIENT OF WATER MIGRATION IN THE SYSTEM SOIL-LYSIMETRIC WATERS

\begin{tabular}{|c|c|c|c|c|c|c|}
\hline \multirow{3}{*}{ Horizon } & \multicolumn{4}{|c|}{ Fluorine in soil } & \multirow{2}{*}{\multicolumn{2}{|c|}{$\begin{array}{l}\text { Fluorine in lysimetric } \\
\text { waters }\end{array}$}} \\
\hline & \multicolumn{2}{|c|}{ Water-soluble } & \multicolumn{2}{|c|}{ Acid-soluble } & & \\
\hline & 1 & 2 & 1 & 2 & 1 & $2 *$ \\
\hline \multicolumn{7}{|c|}{ Irrigation } \\
\hline A arable & 1.33 & 0.0042 & 11.93 & 0.037 & 0.28 & 0.53 \\
\hline A & 1.19 & 0.0034 & 10.92 & 0.032 & 0.29 & 0.51 \\
\hline \multicolumn{7}{|c|}{ Irrigation, phosphogypsum (12 t/ha) } \\
\hline A arable & 2.95 & 0.0088 & 17.08 & 0.051 & 0.70 & 1.27 \\
\hline A & 2.23 & 0.0064 & 13.54 & 0.039 & 1.03 & 1.82 \\
\hline
\end{tabular}

Explanations: 1 - content $(\mathrm{mg} / \mathrm{kg}), 2-$ mobility $(\%), 2 *$ coefficient of water migration.

The coefficient of water migration of fluorine increased 2.5-3.5 times with the introduction of phosphogypsum, which can result in considerable pollution of soil waters and accumulation of the microelement in plants.

\section{CONCLUSIONS}

1. Irrigation of chernozem soils contributes to the redistribution of fluorine in the soil profile and to the increase of its active forms in the arable horizon.

2. Introduction of phosphogypsum contributes to the increase of fluorine in southern chernozems. Application of higher doses (12 t/ha) results in an increase of active fluorine forms in soils and lysimetric waters.

3 . The degree of mobility of fluorides increases with irrigation and this phenomenon is especially pronounced with the introduction of phosphogypsum. 
4. The content of fluorine in lysimetric waters and the coefficient of water migration correlate with its content in soil.

\section{REFERENCES}

[1] Arzhaniova V. S.: Soil Science, 4, 71, 1977.

[2] Gogolev I. N., Bayer R. A., Kulibabin A. G.: Irrigation in Odessa Region. Soil-Ecological and Agrotechnical Aspects. Odessa, 436, 1992.

[3] Khalit o v A. K., R o z in V. I.: On the necessity of excluding fluorine from the composition of mineral fertilizers. Moscow, Nauka, 84, 84, 1980.

[4] Kovda V. A.: Basics of Soil Science. General Theory of Soil-forming Process. Book 2. Izd. Nauka, 468, 1973.

[5] Kudzin Y. K., P a s h ov a V.G.: Soil Science, 2, 30, 1970.

[6] Nikiforova E. M., Gorbunova L. I.: Soil Science, 1, 105, 2001.

[7] P e r e $1 \mathrm{~m}$ a n A. I.: Geochemistry of Landscape. Moscow, 342, 1975.

[8] P i otrow s k a M., Maciak K.: Rocz. Nauk Roln., A 101, 2, 93, 1975.

[9] P o m a zk in a L. V.: Achivments of Modern Biology, 1, 124, 66, 2004.

[10] P o s n y a k S. P.: Irrigated Chernozems of the South-West of Ukraine. Lviv, 240, 1977.

[11] Scientific Fundamentals of Protection and Rational Use of Irrigated Lands of Ukraine. Agrarna Nauka, 624, 2009.

[12] Tri g u b V. I., P o z n y a k S. P.: Fluorine in Chernozems of South-West of Ukraine: Monograph, Lviv, 148, 2008.

[13] Yakovlev A. S., Kaninskin M. A., Terekhova V. A.: Soil Science, 6, 737, 2013.

\section{WPŁYW FOSFOGIPSU NA AKUMULACJĘ I MIGRACJĘ FLUORU W GLEBIE I ROZTWORZE GLEBOWYM}

W pracy przedyskutowano wyniki badań dotyczących wpływu fosfogipsu na migrację i kumulację fluorków w czarnoziemach południowych na północno-zachodnim wybrzeżu Morza Czarnego na Ukrainie. Stwierdzono, że zastosowanie fosfogipsu jako chemicznego środka melioracyjnego nawadnianych czarnoziemów prowadzi do wzrostu fluoru w glebie i wodach glebowych (lizymetrycznych). 